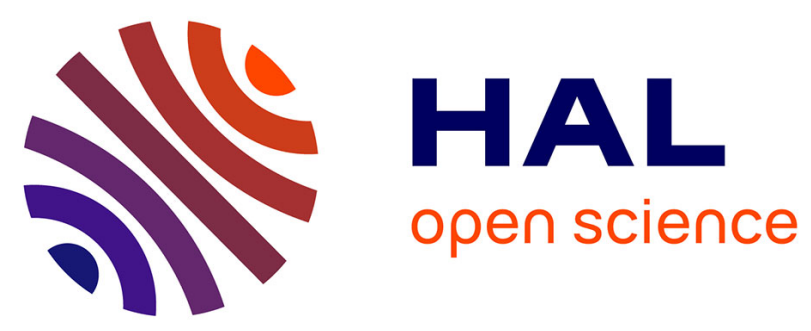

\title{
Time-temperature profiles of infant milk formula in hospitals and analysis of Enterobacter sakazakii growth
}

Philippe Rosset, Véronique Noel, Elisabeth Morelli

\section{To cite this version:}

Philippe Rosset, Véronique Noel, Elisabeth Morelli. Time-temperature profiles of infant milk formula in hospitals and analysis of Enterobacter sakazakii growth. Food Control, 2007, 18 (11), pp.1331-1476. 10.10.1016/j.foodcont.2006.10.004 . hal-00378327

\section{HAL Id: hal-00378327 \\ https://hal-anses.archives-ouvertes.fr/hal-00378327}

Submitted on 24 Apr 2009

HAL is a multi-disciplinary open access archive for the deposit and dissemination of scientific research documents, whether they are published or not. The documents may come from teaching and research institutions in France or abroad, or from public or private research centers.
L'archive ouverte pluridisciplinaire HAL, est destinée au dépôt et à la diffusion de documents scientifiques de niveau recherche, publiés ou non, émanant des établissements d'enseignement et de recherche français ou étrangers, des laboratoires publics ou privés. 


\title{
TIME-TEMPERATURE PROFILES OF INFANT MILK FORMULA IN HOSPITALS AND ANALYSIS OF ENTEROBACTER SAKAZAKII GROWTH
}

\author{
P. ROSSET $\left(^{*}\right)$, V. NOEL, E. MORELLI \\ Agence Française de Sécurité Sanitaire des Aliments, LERQAP, \\ 23 av. du Général de Gaulle, 94709 Maisons-Alfort cedex,France
}

\begin{abstract}
The purpose of this study was to assess the temperature conditions in neonatal care units for the preparation and storage of infant milk formula (IMF) and infant feeding using bottles and continuous feeding syringes. Enterobacter sakazakii in IMF for feeding infants has been chosen as the subject of this study because of the high risk incurred by IMF manufacture without total microbial destruction and the high sensitivity and mortality rates of this population group.

From IMF preparation till neonate feeding, time-temperature profiles of IMF samples were monitored and analysed. In order to show the health impact of this data, potential E. sakazakii growth was calculated. As IMF can be also contaminated with Salmonella, potential Salmonella growth was also calculated. However potential Enterobacter sakazakii growth data were only analyzed because of Enterobacter sakazakii and Salmonella spp data being close.
\end{abstract}

The study of 25 neonatal care units in 15 hospitals showed that the final potential growth for bottles depended on different parameters: initial water temperature, room temperature where IMF was prepared, cold storage temperature and time, reheating temperature and time. One parameter was not usually enough to determine the final growth increment alone and a well controlled and high performance stage could result in an incorrect food safety indication if the other stages are less effective.

On the other hand, the final potential growth for the continuous feeding syringes depended mainly on the feeding period since the IMF was kept in a particularly high ambient air temperature $(\approx$ $25^{\circ} \mathrm{C}$ ) in the infant's bedroom. This stage would be controlled first (with a cold syringe cover for example); then, as for bottles, the other stages would be controlled to result in a correct food safety indication.

Keywords: Risk factors; Predictive microbiology; infant milk formula, Enterobacter sakazakii

\section{Introduction}

Enterobacter sakazakii in infant milk formula (IMF) has been implicated in infant infections, especially among high-risk infants who are premature, have a low birth weight or are immunocompromised. The overall incidence of disease due to Enterobacter sakazakii is relatively low, with about 50 cases among 60 days old infants reported worldwide over the last 40 years (Iversen, Forsythe, 2003; Lehner, Stephan, 2004). Data on these infants indicated most of them were pre-terme, below 37 weeks gestation, and had a low birth-weight, below $2500 \mathrm{~g}$, or peripartum complications (Lai, 2001). Mortality rates of 40 to 80\% (Nazarowec-White, Farber, 1997a; Edelson-Mammel, Buchanan, 2004) have been reported. Survivors often suffer from serious brain damage such as hydrocephalus, quadriplegia and late neural development. Up until now, due to the limited information available on E. sakazakii exposure, the dose-response curve, probably with a linear relationship (Lehner, Stephan, 2004), has not been developed.

\footnotetext{
*Author’s details: Fax +33.143.689.762. E-mail address: p.rosset@afssa.fr
} 
When breastfeeding is not possible, infants are fed with infant formula containing protein from cow's milk or soja. The nutritional composition of these products complies with the standards defined in directives (Commission Directives 91/321/EEC, 96/4/EC, 199/50/EC and 1999/21/EC)

Provided by manufacturers, these products are ready-to-use in liquid or powder forms. While all liquid forms are sterile, the microbial (mainly Enterobacter sakazakii, Salmonella) destruction is never total in milk powder forms. However, none of these sterile forms are used for feeding highrisk infants because they have to be adjusted according to nutritional and/or medical individual prescriptions.

Because IMF is not sterile, good hygienic practices (i.e. rehydratation, cold storage and reheating) for its preparation and distribution to infants are crucial in order to prevent secondary contamination and multiplication. Public health officials such as the World Health Organization (WHO), and French Food Safety Agency (AFSSA) provide recommendations (WHO, 2004; AFSSA, 2005) for the use of IMF. Recent outbreaks due to Enterobacter sakazakii in IMF - 9 cases in 4 different hospitals, 2 seriously ill and 2 deaths in October-December 2004 in France (InVS, 2004; French Ministry for Solidarity, Health and the Family, 2004) - again highlight the extent to which these potential health risks must be controlled.

The purpose of this study was to assess temperature conditions in hospitals for the preparation and storage of IMF and feeding it to infants. In order to show the health impact of IMF, Enterobacter sakazakii and Salmonella spp growths were predicted using standard predictive microbiology models (van Gerwen, Zwietering, 1998).

\section{Materials and methods}

\section{Sampling area and materials}

This study was conducted in 25 neonatal care units of 15 public hospitals located in Paris (6) and its suburbs (9).

Two different feeding methods were studied according to oral or enteral nutrition. In the case of oral nutrition, IMF is poured into bottles, stored in a cold cabinet, reheated and consumed. In the case of enteral nutrition instead of (or in addition to) oral nutrition, IMF is collected in a syringe and stored in a cold cabinet until consumption. For feeding, the syringe is placed in an automatic continuous enteral nutrition system and connected with enteral tubing to the nasogastric tube. This system remains in place at room temperature for several hours $(\leq 3 \mathrm{hrs}$.). All these studies were on powdered IMF.

According to the French Public Health Code (Decree No. 98-899, 1998), all of the health establishments studied have a specific room intended for IMF reconstitution. In all the healthcare establishments studied, bottles and feeding syringes were prepared in advance, in the morning, for a consumption period of 24 hours. As infants are generally fed every 3 hours, the subsequent 24 hours could be divided up into 8 feeding periods.

\section{Temperature measurement}

Temperature was measured by introducing time temperature indicators (TTIs) (Proges Plus, Willems, France) into reconstituted powdered infant formula. Temperature was monitored throughout the preparation and distribution stages: preparation, cold storage, possible transportation 
to a neonatal department, feeding. Measuring started as soon as the first bottle/syringe was prepared. Both feeding methods (bottle, continuous feeding syringe) were studied. For each, IFM was studied in the best and the worst conditions. For feeding bottles, the best conditions were the first feeding period and the worst were the last feeding period. For feeding syringes, the best conditions were the first feeding period and a feeding during one hour; the worst were the last feeding period and a feeding during three hours.

\section{Model for calculation of the potential microbial growth}

Modeling was based on simple and standard predictive microbiology models. The chosen primary model is the exponential growth, without lag phase or stationary phase (fail-safe choice):

$$
N_{i+1}=N_{i} \exp \left(\mu_{i} t_{i}\right) \Leftrightarrow \ln \left(\frac{N_{i+1}}{N_{i}}\right)=\mu_{i} t_{i}
$$

where $\mathrm{N}_{\mathrm{i}}$ (resp. $\mathrm{N}_{\mathrm{i}+1}$ ) is the number of microorganisms (CFU/g) at time $\mathrm{i}$ (resp $\mathrm{i}+1$ ), $\mu_{\mathrm{i}}$ is the growth rate (hour ${ }^{-1}$ ) assumed constant between $\mathrm{i}$ and $\mathrm{i}+1$, and $\mathrm{t}_{\mathrm{i}}$ is the timeframe (hours) between $\mathrm{i}$ and $\mathrm{i}+1$.

Thus, for each timeframe between $\mathrm{i}$ and $\mathrm{i}+1$, the microbial population $\mathrm{N}$ is multiplied by $\exp \left(\mu_{\mathrm{i}} \mathrm{t}_{\mathrm{i}}\right)$ and the growth increment during this period is $\mathrm{N}_{\mathrm{i}+1}-\mathrm{N}_{\mathrm{i}}$. This relation can be also expressed in decimal logarithm, which is easier to interpret:

$$
\log \left(\mathrm{N}_{\mathrm{i}+1}\right)-\log \left(\mathrm{N}_{\mathrm{i}}\right)=\frac{\mu_{\mathrm{i}} \mathrm{t}_{\mathrm{i}}}{\ln (10)}
$$

The chosen secondary model is a cardinal temperature model with inflection (CTMI) (Rosso, 1993):

$$
\begin{array}{|l|l}
\begin{array}{l}
\text { if } \mathrm{T}_{\mathrm{i}} \leq \mathrm{T}_{\min } \\
\text { or if } \mathrm{T}_{\mathrm{i}} \geq \mathrm{T}_{\max }
\end{array} & \mu\left(\mathrm{T}_{\mathrm{i}}\right)=0 \\
\text { if } \mathrm{T}_{\min }<\mathrm{T}_{\mathrm{i}}<\mathrm{T}_{\max } & \mu\left(\mathrm{T}_{\mathrm{i}}\right)=\frac{\mu_{\text {opt }}\left(\mathrm{T}_{\mathrm{i}}-\mathrm{T}_{\max }\right)\left(\mathrm{T}_{\mathrm{i}}-\mathrm{T}_{\min }\right)^{2}}{\left(\mathrm{~T}_{\mathrm{opt}}-\mathrm{T}_{\min }\right)\left[\left(\mathrm{T}_{\mathrm{opt}}-\mathrm{T}_{\min }\right)\left(\mathrm{T}_{\mathrm{i}}-\mathrm{T}_{\mathrm{opt}}\right)-\left(\mathrm{T}_{\text {opt }}-\mathrm{T}_{\max }\right)\left(\mathrm{T}_{\text {opt }}+\mathrm{T}_{\min }-2 \mathrm{~T}_{\mathrm{i}}\right)\right]}
\end{array}
$$

where $\mathrm{T}_{\mathrm{i}}$ is the temperature $\left({ }^{\circ} \mathrm{C}\right)$ assumed constant between $\mathrm{i}$ et $\mathrm{i}+1 ; \mathrm{T}_{\min }$ is the theorical minimal temperature $\left({ }^{\circ} \mathrm{C}\right)$ of the species; $\mathrm{T}_{\max }$ is the theorical maximal temperature $\left({ }^{\circ} \mathrm{C}\right)$ of the species ; $\mathrm{T}_{\text {opt }}$ is the theorical optimal temperature $\left({ }^{\circ} \mathrm{C}\right)$ of the species ; $\mu_{\text {opt }}$ is the growth rate (hour ${ }^{-1}$ ) of the species in the food at temperature $\mathrm{T}_{\mathrm{opt}}$

From (A) and (C), the logarithm microbial increment for each timeframe is:

(D) $\log \left(\mathrm{N}_{\mathrm{i}+1}\right)-\log \left(\mathrm{N}_{\mathrm{i}}\right)=\frac{\mathrm{t}_{\mathrm{i}}}{\ln (10)} \times \frac{\mu_{\mathrm{opt}}\left(\mathrm{T}_{\mathrm{i}}-\mathrm{T}_{\mathrm{max}}\right)\left(\mathrm{T}_{\mathrm{i}}-\mathrm{T}_{\mathrm{min}}\right)^{2}}{\left(\mathrm{~T}_{\mathrm{opt}}-\mathrm{T}_{\min }\right)\left[\left(\mathrm{T}_{\mathrm{opt}}-\mathrm{T}_{\min }\right)\left(\mathrm{T}_{\mathrm{i}}-\mathrm{T}_{\mathrm{opt}}\right)-\left(\mathrm{T}_{\mathrm{opt}}-\mathrm{T}_{\mathrm{max}}\right)\left(\mathrm{T}_{\mathrm{opt}}+\mathrm{T}_{\min }-2 \mathrm{~T}_{\mathrm{i}}\right)\right]}$

where $\mathrm{N}_{\mathrm{i}}\left(\right.$ resp. $\mathrm{N}_{\mathrm{i}+1}$ ) is the number of microorganisms (CFU/g) at time $\mathrm{i}($ resp $\mathrm{i}+1)$; $\mathrm{t}_{\mathrm{i}}$ is the time duration (hours) between $\mathrm{i}$ and $\mathrm{i}+1 ; \mathrm{T}_{\mathrm{i}}$ is the temperature $\left({ }^{\circ} \mathrm{C}\right)$ assumed constant between $\mathrm{i}$ et $\mathrm{i}+1 ; \mathrm{T}_{\min }$ is the theorical minimal temperature $\left({ }^{\circ} \mathrm{C}\right)$ of the species; $\mathrm{T}_{\max }$ is the theorical maximal temperature $\left({ }^{\circ} \mathrm{C}\right)$ of the species; $\mathrm{T}_{\text {opt }}$ is the theorical optimal temperature $\left({ }^{\circ} \mathrm{C}\right)$ of the species; $\mu_{\text {opt }}$ is the growth rate (hour $\left.{ }^{-1}\right)$ of the species in the food at temperature $\mathrm{T}_{\mathrm{opt}}$

For $n$ successive steps, the total growth increment is: 


$$
\Delta \log =\frac{\mu_{\mathrm{opt}}}{\ln (10)} \times \sum_{\mathrm{i}=1}^{\mathrm{n}} \mathrm{t}_{\mathrm{i}} \frac{\left(\mathrm{T}_{\mathrm{i}}-\mathrm{T}_{\mathrm{max}}\right)\left(\mathrm{T}_{\mathrm{i}}-\mathrm{T}_{\min }\right)^{2}}{\left(\mathrm{~T}_{\mathrm{opt}}-\mathrm{T}_{\min }\right)\left[\left(\mathrm{T}_{\mathrm{opt}}-\mathrm{T}_{\min }\right)\left(\mathrm{T}_{\mathrm{i}}-\mathrm{T}_{\mathrm{opt}}\right)-\left(\mathrm{T}_{\mathrm{opt}}-\mathrm{T}_{\max }\right)\left(\mathrm{T}_{\mathrm{opt}}+\mathrm{T}_{\min }-2 \mathrm{~T}_{\mathrm{i}}\right)\right]}
$$

where $t_{i}$ is the timeframe (hours) between $i$ and $i+1 ; T_{i}$ is the temperature $\left({ }^{\circ} \mathrm{C}\right.$ ) assumed constant between $\mathrm{i}$ and $\mathrm{i}+1 ; \mathrm{T}_{\min }$ is the theoretical minimum temperature $\left({ }^{\circ} \mathrm{C}\right)$ of the species; $\mathrm{T}_{\max }$ is the theoretical maximum temperature $\left({ }^{\circ} \mathrm{C}\right)$ of the species; $\mathrm{T}_{\mathrm{opt}}$ is the theoretical optimum temperature $\left({ }^{\circ} \mathrm{C}\right)$ of the species; $\mu_{\mathrm{opt}}$ is the growth rate $\left(\right.$ hour $^{-1}$ ) of the species in the food at temperature $\mathrm{T}_{\mathrm{opt}}$

Thus the calculation of the potential microbial growth requires four microbial values to be determined: the theoretical growth temperatures $\left(T_{\min }, T_{\max }, T_{\mathrm{opt}}\right)$, only on the basis of the studied bacterium; the optimal growth rate $\left(\mu_{\mathrm{opt}}\right)$, depending on the studied bacterium and the type of food.

\section{Calculation of potential Enterobacter sakazakii growth}

Minimum temperature $\left(\mathrm{T}_{\min }\right)$ was determined at $+5.5^{\circ} \mathrm{C}$ according to Nazarowec-White and Farber (1997a) and optimum $\left(\mathrm{T}_{\text {opt }}\right)$ and maximum $\left(\mathrm{T}_{\max }\right)$ temperatures at $+40^{\circ} \mathrm{C}$ and $+46.8^{\circ} \mathrm{C}$ respectively according to Iversen, Lane and Forsythe (2004).

The growth rates $(\mu)$ (or generation times) of Enterobacter sakazakii in IMF for different temperatures (Table 1) were estimated using MicroFit ${ }^{\circledR}$ software (Institute of Food Research, Norwich, UK). The optimum growth rate $\left(\mu_{\mathrm{opt}}\right)$ was estimated by fitting the secondary model (Rosso, 1993) using the solver function of Excel. The estimated optimum Enterobacter sakazakii growth rate was $2.55 \mathrm{~h}^{-1}$.

According to Nazarowec-White and Farber (1997b), the D-values ranged from 54-79 min. at $52^{\circ} \mathrm{C}$ and the $\mathrm{z}$ value is $5.6^{\circ} \mathrm{C}$. These thermotolerance parameters did not allow significant $E$. sakazakii destruction for the collected time temperature profiles, the time over $47^{\circ} \mathrm{C}$ being relatively short. Thus the model for calculating the potential growth was not modified.

To compare the results, the potential growth results were expressed in decimal log (CFU/g) and 3 groups were defined: below $1 \log _{10}$; between $1 \log _{10}$ and $2 \log _{10}$; above $2 \log _{10}$.

\section{Comparison with potential Salmonella growth}

As with any milk product, IMF can be contaminated with Salmonella. A recent infant outbreak caused by Salmonella Agona in IMF (InVS, 2005; Espié et al., 2005) again highlights the extent to which these potential health risks must be controlled. It was therefore interesting to calculate the potential growth for Salmonella as well, and to compare both these health risks.

The infection cases due to Salmonella in IMF reported over the last twenty years were caused by different Salmonella enterica serovars: Agona (2005) in France (Espié et al, 2005; InVS, 2005), London (2000) in Korea (Jong-Ku et al, 2004), Anatum (1996) in Europe (Surveillance report, 1997), Bredeney in Australia in 1977 (Forsyth et al, 2003), Ealing (1985) in UK (Row et al, 1987), Tennessee (1993) in USA and Canada (Centers of Disease Control and Prevention Canada and United States, 1993), Virchow (1994) in Spain (Ruiz et al, 1995). Consequently it was decided to determine the growth parameters for Salmonella enterica species and not for a defined serovar.

According to Rosso (1995), minimum temperature $\left(\mathrm{T}_{\min }\right)$ was $+5^{\circ} \mathrm{C}$, optimum $\left(\mathrm{T}_{\mathrm{opt}}\right)$ temperature $40^{\circ} \mathrm{C}$ and maximum $\left(\mathrm{T}_{\max }\right)$ temperature $47.5^{\circ} \mathrm{C}$.

The optimum growth rate $\left(\mu_{\mathrm{opt}}\right)$ was estimated using Growth Predictor ${ }^{\circledR}$ software (Institute of Food Research, Norwich, UK) based on $\mathrm{pH}$ values observed in our laboratory for different IMF samples 
currently used. The pH average was 6.94 and $\mathrm{a}_{\mathrm{w}}$ was the milk value $(0,997)$. The calculated optimum Salmonella spp growth rate was $1.76 \mathrm{~h}^{-1}$.

\section{$\underline{\text { Results and discussion }}$}

In 25 neonatal care units, 86 bottle preparations and 93 continuous feeding syringe preparations were studied and 179 time-temperature profiles were collected.

\section{Time-temperature profiles analysis}

The time-temperature profiles were analysed in Table 2. They are based on successive stages: preparation in the IMF room, delivery to a neonatal care unit (optional stage), cold storage, bottle reheating, feeding (see Figures 1 and 2).

For the purpose of assessing the impact of the preparation, storage and distribution of IMF on the potential growth results, parameters were defined: initial IMF temperature, time at room temperature, temperature at the end of cold storage, reheating time and temperature at the end of reheating (see Table 2).

Regarding IMF preparation, most of the profiles (74.9\%) showed that the IMF was kept at room temperature for a short time ( $\leq 15$ minutes): the bottles/syringes were generally prepared in batches and were then stored in a cold cabinet.

Initial IMF temperature was between $6^{\circ} \mathrm{C}$ and $18^{\circ} \mathrm{C}$ in $34 \%$ of cases ( 8 hospitals). It was due to the use of refrigerated water for the IMF preparation in an air-conditioned feeding room. This is quite important as the IMF volume (30 ml) was very sensitive to temperature variations.

In $63.8 \%$ of cases (5 hospitals), initial IMF temperature was between 18 and $30^{\circ} \mathrm{C}$ and was the result of a preparation in a feeding room without any air-conditioning equipment.

Initial IMF temperature of over $30^{\circ} \mathrm{C}$ was observed in $2.2 \%$ of cases (2 hospitals). It was due to water heating, this practice enabled components to mix more easily. In any case, blast chiller was used for quickly cooling down IMF.

Regarding IMF cold storage, the temperature at the end of cold storage depends on the time for which it is stored. The first and last feeding period were therefore analysed separately.

As the first period was short (a few hours after IMF preparation), the profiles (82,8\%) with a final cold storage temperature of over $4^{\circ} \mathrm{C}$ were generally due to a timeframe in the cold cabinet that was too short for cooling down the IMF.

On the other hand, for the last feeding period (around 24 hours after IMF preparation), the profiles (78.2\%, 10 care units) with a final cold storage temperature of over $4^{\circ} \mathrm{C}$ were due to an ineffective or incorrectly regulated cold cabinet. In these care units (10/25 care units) the cold storage cabinet was therefore not able to keep IMF at $4^{\circ} \mathrm{C}$ or below, according to recommendations (AFSSA, 2005; Tuoby PG. and Jacobs M., 2005; Agostini et al., 2004).

For IMF reheating, microwaves were used in two hospitals (10.5\% bottle profiles).

The profiles (36\%) with a long reheating time (over 30 minutes) were generally the result of the use of collective hot water batch.

At the end of reheating, the temperature was below $47^{\circ} \mathrm{C}$ for $54,6 \%$ bottles: therefore in case of IMF contamination with Enterobacter sakazakii and/or Salmonella, microbial multiplication would be possible. 


\section{Potential growth analysis}

As potential Enterobacter sakazakii and Salmonella spp growths data were close (see Table 3), potential Enterobacter sakazakii growth data were only analyzed.

Bottles (see Table 3):

Most potential E. sakazakii growth increments (69\%) were under $1 \log _{10}$ and nearly all (98\%) were under $2 \log _{10}$. In all cases, no significant differences were observed for the feeding period $(\mathrm{p}<0,0001)$. Only one profile $(2 \%)$ showed an increment $\left(\approx 3 \log _{10}\right)$ of over $2 \log _{10}$. This result was explained by the combination of long storage time (22 hours) and high storage temperature (around $+14^{\circ} \mathrm{C}$ ) in an ineffective or incorrectly regulated neonatal care unit cabinet.

Continuous feeding syringes (see Tables 3 and 4):

The potential E. sakazakii growth depends mainly on the feeding period (first feeding: 1 hour; last feeding: 3 hours) at room temperature $\left(\geq 25^{\circ} \mathrm{C}\right)$. Thus, the maximum increments for this stage were $0,7 \log _{10}$ for 1 hour feeding time and $2 \log _{10}$ for 3 hours feeding time.

For one care unit, the situation was completely different: the continuous feeding syringe was placed in a cold cover which kept the IMF temperature under $+10^{\circ} \mathrm{C}\left(+5^{\circ} \mathrm{C} \leq \mathrm{t} \leq+9.5^{\circ} \mathrm{C}\right)$ throughout the feeding period. For 3 hours feeding time, the increment was $0,02 \log _{10}$.

The 47 profiles (50.5\%) with an final increment of under $1 \log _{10}$ were mainly first feeding profiles (44 profiles). On the other hand the 46 profiles (49.5\%) with increment over of $1 \log _{10}$ were mainly last feeding profiles (41 profiles). Among the increments ( 7 profiles, $7.5 \%$ ) of over $2 \log _{10}$, only one was a first feeding profile. This result could be explained, as with bottles, by the combination of long storage time and high cold storage temperature.

Bottles and continuous feeding syringes (see Table 4):

The phase with the biggest influence on overall potential growth was the cold storage in care units. Fortunately, an ineffective cold storage was exceptional (3 care unit cold cabinets).

Transportation from the IMF room to the care unit, however, (when this stage takes place) had little influence on overall potential growth because this stage was generally short ( $<15 \mathrm{~min}$.) or, in the event of longer journeys, the equipment was adapted (cold block in trolley, etc.).

\section{Discussion}

The worst potential growth values were explained by a combination of different parameters: high initial IMF temperature (water being warmed before mixing with infant milk formula and being refrigerated without any fast chilling, IMF kept at room temperature for a long time), high storage temperatures (ineffective or incorrectly regulated cold cabinet), long reheating time (collective heating bain marie).

For example, a high initial IMF temperature $\left(27.5^{\circ} \mathrm{C} \leq \mathrm{t} \leq 33^{\circ} \mathrm{C}\right.$ for 40 minutes $\left.\approx 0.4 \log _{10}\right)$ determined no effect on the final potential growth $\left(\approx 1.3 \log _{10}\right)$ if the cold storage temperature was low and the cold storage time long $\left(+3.5^{\circ} \mathrm{C} \leq \mathrm{t} \leq+7.5^{\circ} \mathrm{C}\right.$ for 24 hours $\left.=0.01 \log _{10}\right)$

On the other hand, air-conditioning equipment in the IMF room could result in an incorrect food safety indication if it was not correctly regulated (air temperature $\approx 20^{\circ} \mathrm{C}$ ) and the IMF was kept at room temperature for a long time (105 minutes, IMF temperature rising from 10 to $20^{\circ} \mathrm{C} \approx 0.4$ $\left.\log _{10}\right)$. 
For the continuous feeding syringes, the high potential growth values were mainly due to the feeding period because of the IMF was kept in the infant's room at room temperature $\left(\approx 25^{\circ} \mathrm{C}\right)$ during a long time. The other stages have to be also are effective.

The use of a cold cover for keeping the IMF at low temperature in a continuous feeding syringe ensured good food safety, this effect $\left(+5^{\circ} \mathrm{C} \leq \mathrm{t} \leq+9.5^{\circ} \mathrm{C}\right.$ during 3 hours), the result $\left(=0,018 \log _{10}\right)$ was completely modified by a long storage time in an ineffective or incorrectly regulated cold cabinet (IMF: $+5^{\circ} \mathrm{C} \leq \mathrm{t} \leq+12.5^{\circ} \mathrm{C}$ for 24 hours $\left.\approx 0.8 \log _{10}\right)$.

\section{Conclusion}

This study assessed temperature conditions in public health establishments for the preparation and storage of infant milk formula (IMF) and feeding it to infants. In order to show the health impact of time-temperature evolution in IMF, Enterobacter sakazakii potential growth was calculated.

This assessment showed that the final increment was the result of a combination of different parameters: initial IMF temperature, IMF room temperature, cold storage temperature, cold storage time, reheating temperature, reheating time. One parameter was not usually enough to determine the final increment alone. Each manufacturing stage must be well-controlled and effective, good hygienic practices respected at every stage and the equipment (especially cold cabinets) effective and correctly regulated.

\section{$\underline{\text { Acknowledgements }}$}

The authors are especially grateful to the neonatal care unit managers who participated in this project. The authors would also like to thank Carpentier B., Cornu M. and Poumeyrol G. for their technical help.

\section{References}

AFSSA (2005) Recommandations d'hygiène pour la préparation et la conservation des biberons (Hygiene recommendations for the preparation, handling and storage of feeding bottles). Ed AFSSA, 114 p.

http://www.afssa.fr/Ftp/Afssa/32117-32118.pdf

Agostini C., Axelsson I., Goulet O., Koletzko B., Michaelsen KF., Puntis JW., Shamir R., Szajewska H., Turck D., Vandenplas Y., Weaver LT. (2004) Preparation and handling of powdered infant formula: A commentary by the ESPGHAN Committee on nutrition. Journal of Paediatric Gastroenterology and Nutrition, 39(4),320-322

Centers of Disease Control and Prevention Canada and United States (1993) Salmonella serotype Tennessee in powdered milk products and infant formula. Jama, 270, 4, 432

Commission Directive 91/321/CEE (1991) on infant formulae and follow-on formulae. Official Journal of the European Communities, 04.07.1991, L175, p 35

Commission Directive 96/4/EC (1996) amending Directive 91/321/EEC on infant formulae and follow-on formulae. Official Journal of the European Communities, 28.02.1996, L49 
Commission Directive 199/50/EC (1999) amending Directive 91/321/EEC on infant formulae and follow-on formulae. Official Journal of the European Communities, 02.061999, L139

Commission Directive 1999/21/EC (1999) on dietary foods for special medical purposes. Official Journal of the European Communities, 07.04.1999, L91/29

Decree $N^{\circ} 98-899$ of $9^{\text {th }}$ October 1998 modifying tittle 1 of the Book VII of the French Public Health Code and relative to public and private healthcare establishments practising obstetrics, neonatalogy or neonatal intensive care.

Edelson-Mammel S.G., Buchanan R.L. (2004). Thermal inactivation of Enterobacter sakazakii in rehydrated infant formula. Journal of Food Protection, 67, 1, 60-63

Espié E., Weill F.X., Brouard C., Capek I., Delmas G., Forgues A.M., Grimont F., de Valk H. (2005) Nationwide outbreak of Salmonella enterica serotype agona infections in infants in France, linked to infant milk formula, investigations ongoing. Eurosurveillance, 10, 1-3, 54

Published online as e-alert, 9 march 2005 : http://www.eurosurveillance.org/ew/2005/050303.asp

Forsyth J.R.L., Bennett N.McK., Hogben S., Hutchinson E.M.S., Rouch G., Tan A., Taplin J. (2003) The year of the salmonella seekers - 1977. Australian New Zealand Jour. Public Health, 27, 4, 385-9

van Gerwen, S.J., Zwietering, M.H. (1998). Growth and inactivation models to be used in quantitative risk assessments. Journal of Food Protection, 61, 1541-1549.

InVS (2005) Epidémie de salmonellose à Salmonella enterica sérotype agona chez des nourrissons, France, janvier-avril 2005. Point final de l'investigation au 10 juin 2005.

http://www.invs.sante.fr/presse/2005/le_point_sur/salmonella_agona_150605/index.html

InVS (2004) Infections à Enterobacter sakazakii chez des nouveaux-nés ayant consommé du Pregestimil ${ }^{\circledR}$, préparation pour alimentation des nourrissons et enfants en bas-âge, France, octobre à décembre 2004.

http://www.invs.sante.fr/recherche/index2.asp?txtQuery=sakazakii

Iversen C., Forsythe S. (2003) Risk profile of Enterobacter sakazakii, an emergent pathogen associated with infant milk formula. Trends Food Sc. Technol., 14, 11, 443-454

Iversen C., Lane M., Forsythe S.J. (2004) The growth profile, thermotolerance and biofilm formation of Enterobacter sakazakii grown in infant formula milk. Letters in Applied Microbiology, 38, 378-382

Jong-Ku Park, Won-Seok Seok, Byoung Joo Choi, Hwang Min Kim, Baek Ken Lim, Sung-Sik Yoon, Shukho Kim, Young-Soo Kim, Joo Young Park (2004) Salmonella enterica serovar London infections associated with consumption of infant formula Yonsei Medical Journal, 45, $\underline{1}$, 43-48

Lai K.K. (2001) Enterobacter sakazakii infections among neonates, infants, children and adults. Case reports and a review of the literature. Medicine, 80, 113-22

Lehner A., Stephan R. (2004) Microbiological, epidemiological and food safety aspects of Enterobacter sakazakii. Journal of Food Protection, 67, 12, 2850-2857 
Ministère des Solidarités, de la Santé et de la Famille (2004) Message d'alerte - Retrait des lots de Prégestimil suite à la survenue d'infections sévères à Enterobacter sakazakii chez des nouveaux-nés prématurés hospitalisés ayant consommé ce produit.

http://www.sante.gouv.fr/htm/actu/pregestimil/sommaire.htm

Nazarowec-White M., Farber J.M. (1997a) Incidence, survival and growth of Enterobacter sakazakii in infant formula. Journal of Food Protection, 60, 3, 226-230

Nazarowec-White M., Farber J.M. (1997b) Thermal resistance of Enterobacter sakazakii in reconstituted dried-infant formula. Letters in Applied Microbiology, 24, 9-13

Rosso. L. (1993) An unexpected correlation between cardinal temperatures of microbial growth highlighted by a new model. Journ. Theor. Biol., 162, 447-463

Rosso, L. (1995) Modélisation et microbiologie prévisionnelle : Elaboration d'un nouvel outil pour l'agro-alimentaire. Thèse de doctorat de l'Université Claude Bernard-Lyon 1 (France), soutenue le 20 septembre, $190 \mathrm{p}$.

Rowe, B., Hutchinson, D.N., Gilbert, R.J., Hales, B.H., Begg, N.T., Dawkins, H.C., Jacob, M., Rae, F.A. (1987) Salmonella ealing infections associated with consumption of infant dried milk. Lancet, october 17, 900-903.

Ruiz J., Nunez M.L., Sempere M.A., Diaz J., Gomez J. (1995) Systemic infections in three infants due to a lactose-fermenting strain of Salmonella Virchow Eur. Journ. Clin. Microbiol. Infect. Dis., $14, \underline{5}, 454-6$

Surveillance report. (1997) Preliminary report of an international outbreak of Salmonella Anatum linked to an infant formula milk. Eurosurveillance, 2, $\underline{3}$, 22-24

Tuohy PG., Jacobs M. (2005) Inquiry into actions of sector agencies in relation to contamination of infant formula with Enterobacter sakazakii. New Zealand Ministry of Health Report, 19 p.

http://www.moh.govt.nz/moh.nsf

WHO (2004) Enterobacter sakazakii and other microorganisms in powdered infant formula: meeting report. WHO Microbiological Risk Assessment Series, №6.

http://www.who.int/foodsafety/publications/micro/mra6/en/index.html 
Figure 1

Time-temperature profiles

Bottle profile (first feeding period) and syringe profile (last feeding period)

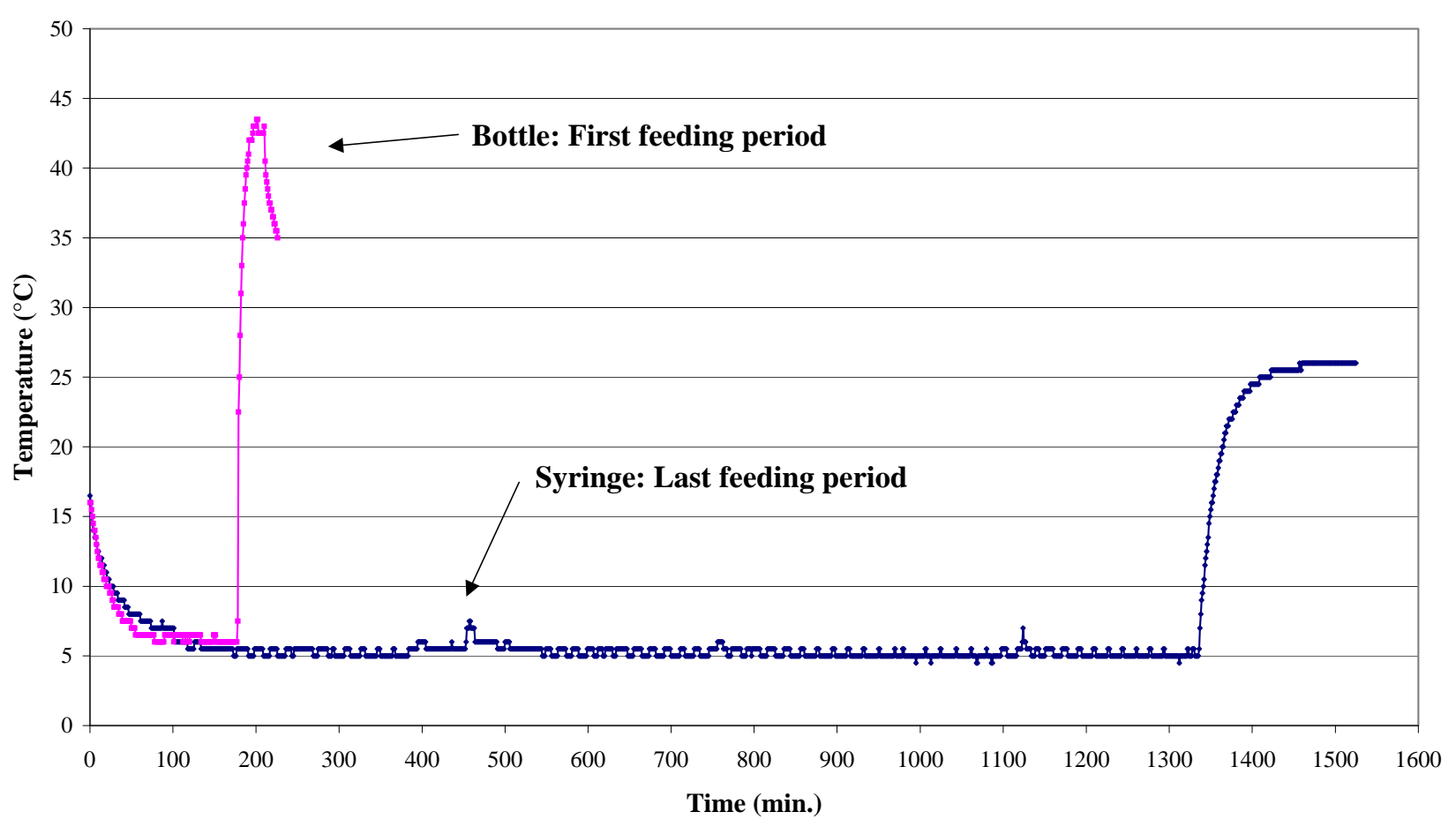

Figure 2

Time-temperature profile: Manufacturing stages (bottle profile)

(a: preparation; b: transport; $c$ : cold storage;

$d$ : reheating; $e_{1}$ : waiting; $e_{2}$ : feeding)

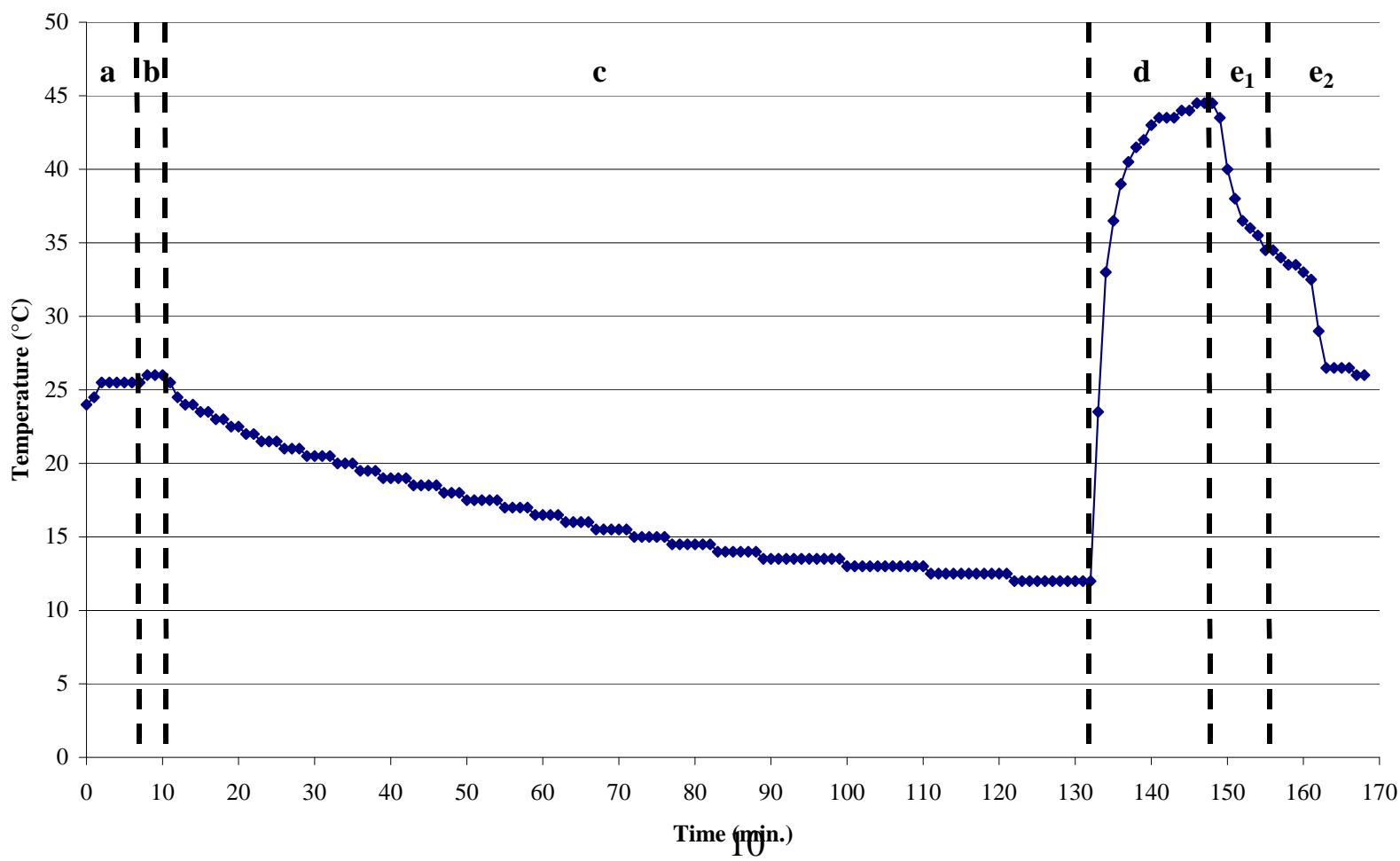


Table 1

Doubling time (h) for Enterobacter sakazakii at different temperatures in IMF

\begin{tabular}{|l|c|c|c|c|c|}
\hline Reference & $\mathbf{6}^{\circ} \mathbf{C}$ & $\mathbf{1 0}^{\circ} \mathbf{C}$ & $\mathbf{2 1}^{\circ} \mathbf{C}$ & $\mathbf{2 3}^{\circ} \mathbf{C}$ & $\mathbf{3 7}^{\circ} \mathbf{C}$ \\
\hline Iversen, Lane \& Forsythe, 2004 & 13.7 & & 1.7 & & 19 \\
& & & & & 21 \\
\hline Nazarowec-White \& Farber, 1997a & & 5.52 & & 0.65 & \\
& & 4.79 & & 0.85 & \\
& & 5.06 & & 0.73 & \\
& & 5.12 & & 0.67 & \\
& & 4.22 & & 0.66 & \\
& & 4.18 & & 0.61 & \\
& & 4.20 & & 0.67 & \\
& & 4.15 & & 0.66 & \\
\hline
\end{tabular}


Table 2

Analysis of the time-temperature profiles (179)

(86 bottles, 93 syringes)

\begin{tabular}{|c|c|c|c|c|c|c|}
\hline Parameter & Minimum & Average & Maximum & \multicolumn{3}{|c|}{ Repartition of the results } \\
\hline \multirow{2}{*}{$\begin{array}{c}\text { Time kept at room } \\
\text { temperature }\end{array}$} & \multirow[t]{2}{*}{$1 \mathrm{~min}}$. & \multirow[t]{2}{*}{$18 \mathrm{~min}}$. & \multirow[t]{2}{*}{$159 \mathrm{~min}}$. & $t \leq 15 \min$ & $15 \min <t \leq 90 \min$ & $t>90 \mathrm{~min}$ \\
\hline & & & & $74,9 \% \quad 134 / 179$ & $19,5 \% \quad 28 / 179$ & $5,6 \% \quad 17 / 179$ \\
\hline \multirow{2}{*}{$\begin{array}{l}\text { Initial IMF temperature } \\
\qquad\left(\mathrm{T}_{0}\right)\end{array}$} & \multirow[t]{2}{*}{$6,5^{\circ} \mathrm{C}$} & \multirow[t]{2}{*}{$20,8^{\circ} \mathrm{C}$} & \multirow[t]{2}{*}{$36^{\circ} \mathrm{C}$} & $T_{0} \leq 18^{\circ} \mathrm{C}$ & $18^{\circ} \mathrm{C}<T_{0} \leq 30^{\circ} \mathrm{C}$ & $T_{0}>30^{\circ} \mathrm{C}$ \\
\hline & & & & $34 \% \quad 61 / 179$ & $63,8 \% \quad 114 / 179$ & $2,2 \% \quad 4 / 179$ \\
\hline \multirow{5}{*}{$\begin{array}{l}\text { Temperature }\left(T_{\mathrm{f}}\right) \\
\text { at the end of cold storage }\end{array}$} & \multirow{2}{*}{\multicolumn{3}{|c|}{ for only first feeding period: }} & $T_{f} \leq 4^{\circ} \mathrm{C}$ & $4^{\circ} \mathrm{C}<T_{f} \leq 8^{\circ} \mathrm{C}$ & $T_{f}>8^{\circ} \mathrm{C}$ \\
\hline & & & & \multicolumn{3}{|c|}{ for only first feeding period: } \\
\hline & $-1^{\circ} \mathrm{C}$ & $8,3^{\circ} \mathrm{C}$ & $20^{\circ} \mathrm{C}$ & $17,2 \%$ & $37,9 \% \quad 33 / 84$ & $44,9 \%$ \\
\hline & \multicolumn{3}{|c|}{ for only last feeding period: } & \multicolumn{3}{|c|}{ for only last feeding period: } \\
\hline & $0^{\circ} \mathrm{C}$ & $6,2^{\circ} \mathrm{C}$ & $16,5^{\circ} \mathrm{C}$ & $21,8 \%$ & $63,2 \% \quad 55 / 87$ & $13 / 87$ \\
\hline \multirow{2}{*}{$\begin{array}{l}\text { Reheating } \\
\text { time duration (t) } \\
\text { (for bottles) }\end{array}$} & \multirow[t]{2}{*}{$25 \mathrm{~s}}$. & \multirow[t]{2}{*}{$23 \mathrm{~min}}$. & \multirow[t]{2}{*}{$83 \mathrm{~min}}$. & $\begin{array}{c}t \leq 2 \min \\
\text { (microwaves) }\end{array}$ & $2 \min <t \leq 30 \min$ & $t>30 \mathrm{~min}$ \\
\hline & & & & $10,5 \% \quad 9 / 86$ & $53,5 \%$ & $31 / 86$ \\
\hline \multirow{2}{*}{$\begin{array}{c}\text { Temperature }\left(\mathbf{T}_{\mathbf{f}}\right) \\
\text { at the end of reheating } \\
\text { (for bottles) }\end{array}$} & \multirow[t]{2}{*}{$31,5^{\circ} \mathrm{C}$} & \multirow[t]{2}{*}{$46,1^{\circ} \mathrm{C}$} & \multirow[t]{2}{*}{$62^{\circ} \mathrm{C}$} & $T_{f} \leq 48^{\circ} \mathrm{C}$ & $48^{\circ} \mathrm{C} \leq \mathrm{T}_{f} \leq 52^{\circ} \mathrm{C}$ & $T_{f}>52^{\circ} \mathrm{C}$ \\
\hline & & & & $54,6 \%$ & $24,4 \%$ & $18 / 86$ \\
\hline
\end{tabular}




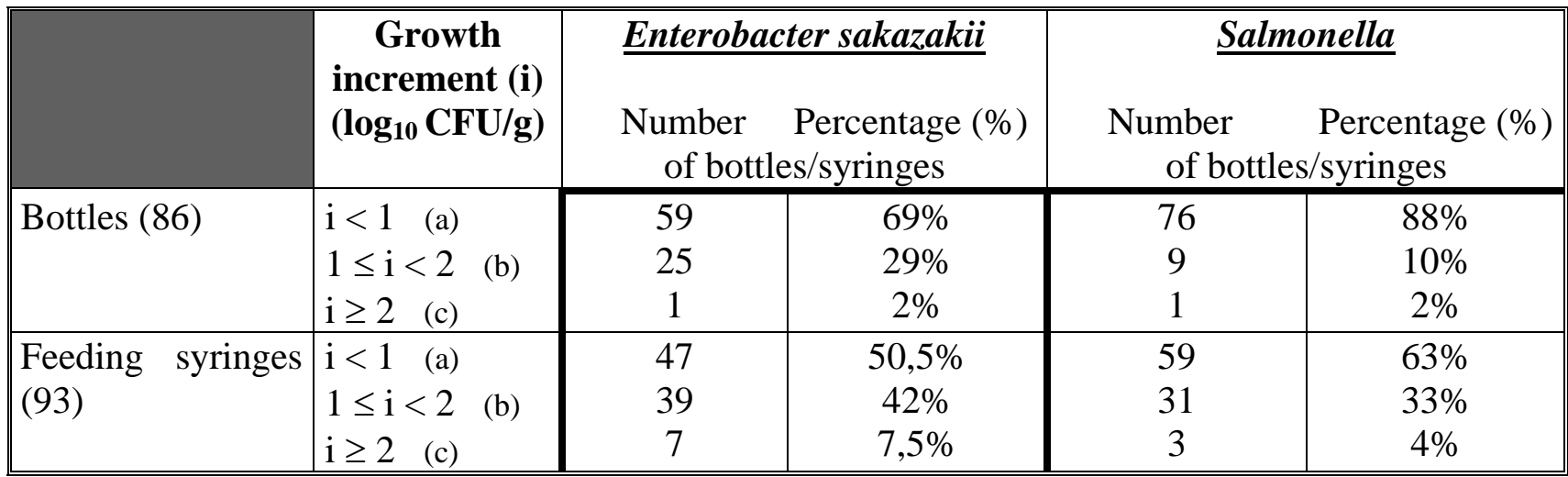
(a): multiplication factor $<10$
(b): multiplication factor $\geq 10$ to 100
(c): multiplication factor $\geq 100$

Table 3

Potential growth for Enterobacter sakazakii and Salmonella in IMF

\begin{tabular}{|c|c|c|c|c|c|c|}
\hline & \multicolumn{6}{|c|}{$\begin{array}{c}\text { Stage } \\
\end{array}$} \\
\hline & $\begin{array}{l}\text { Preparation } \\
\text { at room } \\
\text { temperature }\end{array}$ & \begin{tabular}{|l|} 
Cold storage \\
in IMF room
\end{tabular} & Transport & $\begin{array}{l}\text { Cold storage } \\
\text { in care unit }\end{array}$ & Reheating & Feeding \\
\hline $\begin{array}{l}\text { Bottles: } \\
\text { Maximum increment }\left(\log _{10}\right) \text { : }\end{array}$ & 1,3 & 1,1 & 0,04 & 2,5 & 1,1 & \\
\hline $\begin{array}{l}\text { Feeding syringes: } \\
\text { Maximum increment }\left(\log _{10}\right) \text { : }\end{array}$ & 1,2 & 1,2 & 0,1 & 2,9 & & $\begin{array}{l}1 \text { hour: } 0,7 \\
3 \text { hours: } 2\end{array}$ \\
\hline
\end{tabular}

Table 4

Potential E. sakazakii growth: maximum increments for each stage 